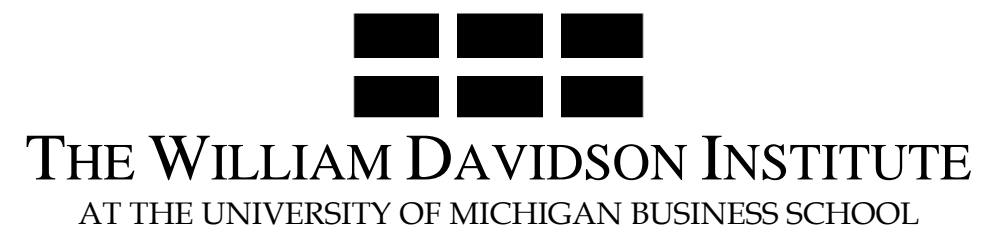

AT THE UNIVERSITY OF MICHIGAN BUSINESS SCHOOL

\title{
INTERNATIONAL BUSINESS AND DEVELOPMENT ECONOMICS: A WINNING COMBINATION Generating a World's View based on Buckley and Casson and Hirschman's Books
}

\author{
By: Tamir Agmon
}

William Davidson Institute Working Paper Number 725

November 2004 


\title{
INTERNATIONAL BUSINESS AND DEVELOPMENT ECONOMICS: A WINNING COMBINATION \\ Generating a World's View based on Buckley and Casson and Hirschman's Books
}

By

\author{
Tamir Agmon* \\ Graduate School of Business \\ The College of Management \\ Rishon LeZion, Israel \\ E mail: agmont@st.colman.ac.il
}

July 2003

Revised, September 2003

Second revision, February 2004

\begin{abstract}
An Abstract
Much of the discussion in economics is concerned with growth. Economic growth can be discussed and measured in terms of a national state. It can be also discussed and measured in terms of a corporation, (often using the term value rather than growth). Development Economics is concerned with growth of countries run by governments; International Business is concerned with the behavior and the value of multinational enterprises run by management. This paper is about the interface between the two. The vehicle used in this paper to explore the interface is a comparative analysis between two very influential books; "The Strategy of Development" by Hirschman, (1958), and the "Future of the Multinational Enterprise" by Buckley and Casson, (1976). The main argument of the paper is that Development Economics and International Business do approach a very similar issue, but they do it from two different dimensions perpendicular to each other. Looking at the whole picture, (the matrix as a whole rather than along the two separate vectors), gives the observer a more meaningful picture. This is done in the paper through a critical comparison of the two texts focusing on the two dimensions on internalization, growth and internalization, investment choices and strategies, and multinational enterprises and the dynamics of development.
\end{abstract}

Keywords: Development Strategy, International Business Theory

JEL classification: F23

\footnotetext{
* Joel and Eric Stern Professor of Applied Research in Microeconomics and Finance, and Dean, Graduate School of Business, The College of Management, Rishon Lezion, Israel.
} 


\section{The Different Path of Development Economics and International Business: An Introduction and a Literature review}

In their book “The Future of the Multinational Enterprise”, (1976), Buckley and Casson have developed some of the most important concepts in the study of the economics of the multinational enterprise, (or the multinational corporation to use the American term). Following the path-breaking early work of Stephen Hymer, (1976), and the following analysis of Kindleberger, (1969), and Caves, (1971), Buckley and Casson established the concept of internalization as the organizing and explanatory paradigm of the development and the international expansion of the multinational enterprise. The popularity of the concept of internalization in the study of the multinational enterprise is evidence to the success of their approach. (A recent issue of JIBS, vol. 34, issue 2, 2003, was devoted to their work).

Buckley and Casson are taking the national states, their markets, and the factors of production they control as inputs in the investment decisions of MNEs. Thus MNEs maximize profits in an imperfect market comprises of many national states. Imperfections in this market are man-made and not a natural phenomenon, (although internalization can be the result of physical impediments as well). In many cases the imperfections are originated, or supported by national states as a part of their policies. Governments are utilizing existing imperfections, and introduce some new laws and regulations as policy tools. (For a discussion of the way that governments are using such instruments see Globerman and Shapiro, 1999).

Sixteen years before the publication of Buckley and Casson's book Hirschman has published his book: "The Strategy of Development", (1958). At the time of the publication of his book Hirschman was one of the major figures in Development Economics both in the conceptual dimension as a researcher and as a Professor of Economics, and in the applied dimension as a consultant to the World Bank. Like “The Future of the Multinational Enterprise” Hirschman’s book was very popular and influential. (By 1972 it was reprinted 15 times). Hirschman’s book, as well as many other publications, seminars, and policy papers have contributed in forming a "view of the world” in the 60's in a similar way that Buckley and Casson's work and all the following developments of the concept of internalization have contributed to the International Business "view of the world". 
Although the Development Economics "view of the world" and the International Business "view of the world" seem to be very different, some will say opposites, this is not the case. Hirschman and Buckley and Casson are coming from different branches of economics, they are focusing on different dimensions, and most important they write and do research in a different social, political, and economic environment. Yet, they are dealing with a similar situation, and being good economists they are coming to similar conclusions.

This paper is about the common basic economics that is common to both Development Economics and International Business. The focus is on Buckley and Casson and on Hirschman because by being excellent proponents of their respective "view of the world" they provide us with insights regarding the interface between International Business and Development Economics, an interface that generates a fuller and more complex "view of the world". In Development Economics the active party is the national state that maximizes the welfare of its residents, and in International Business the active party is the multinational enterprise (MNE) that maximizes the value of its shareholders. By combining both "views of the world" the result is a more complex, but more real world where the focus is on the interaction between state and MNE and the state and people act as maximizers in the two organizations to whom they belong; the state and the MNE.

This is done in this paper through a comparative analysis of the two books: "The Strategy of Development”, (1958), and “The Future of the Multinational Enterprise”, (1976). However, the critical analysis of the two books is used as an intellectual container only. The message goes beyond the authors and the books. The message is that Development Economics (DE) and International Business (IB) have focused each on one dimension of a global issue: how production, (in the most inclusive definition), is distributed among countries, (IB), and how it affects global income distribution, (DE). Reading Buckley and Casson 1976 book side by side with Hirschman 1958 book contributes to a better understanding of the world at the beginning of the $21^{\text {st }}$ century. The two books put together symbolize the winning combination of International Business and Development Economics as a way to generate an economic world view of the complex world of our time. 
Both Development Economics and the economics of International Business were developed in a certain time frame in history. They reflect temporal needs and provided answers to current questions at their time. In the post WWII period modern national states perceived the economic welfare of their citizens as a part of their responsibility. This is true for most national states, developed and developing. The literature of Development Economics provides us with a discussion of the ways by which national states act to do that. (Although the discussion in the literature is focused on developing countries it can be easily extended to developed countries as well). Development Economics grew up as a field of economics as a result of the process of industrialization in developing countries in the post WW II period. Following the political and social concepts of the time, as well as the need to rebuild many countries after the war and the end of the colonial period, the focus was on government policies and how they can affect the welfare of the people residing in a given state.

Globalization as an economic, social, and political theme came later. It grew up together with the liberalization of trade and capital flows in the last third of the $20^{\text {th }}$ century. The focus was on free market as represented by the Monetarists and similar approaches to economic policy. The preferred vehicle of growth, and implicitly of income distribution was the MNE that transcends political borders. The aim of the MNE as a firm is to maximize the wealth of its shareholders, (according to the narrower definition of financial economics), or that of its stakeholders, (according to the broader view of the organizational theory paradigm). The economics of International Business that was developed hand in hand with the progress of liberalization and integration in the world's markets. The economics of International Business provides analytical tools and concepts that goes together with the idea that the firm and its shareholders are the focal point of economic activities. Maximizing the value of firms will bring about maximum welfare for all. At the extreme the world becomes one "global village" where the free market reigns supreme.

Yet, as Kobrin (2000) argues the MNEs themselves are creatures of the division of the world into national states. The mere term Multinational Enterprise indicates a world divided into national states. 
The beginning of the $21^{\text {st }}$ century has shown us that globalization and liberalization did not create the euphomistic "global village". In a dialectical way the process of globalization emphasizes the function of the government as a representative of the residents in a given state. Nationalism is on the rise. Yet, the process of globalization did create real multinational enterprises with their own constituency and their own power base. In economics like in physics any movement creates a counter-movement. The concentration of power at the MNEs resulted in more power at the hands of the national state. One outcome of this process is an oligopolistic market where only large organizations, national states and MNEs can compete effectively. In such a market internalization and negotiation are two complementary key phrases. (For a formal analysis of such a model see Agmon and Khouri, 1991).

Governments do look at the MNEs of the world as potential providers of production, distribution, $R \& D$ and other forms of knowledge, all of them are sources of income and welfare for their residents. One way by which governments act to maximize their objective function is by enticing firms to locate production, R\&D, and other income-producing activities within their borders. Governments maximize the welfare of their citizens subject to a vector of possible location decisions by managements of MNEs. MNEs look at governments as providers of location advantages from the physical to the fiscal. Managements of MNEs maximize their value subject to a vector of possible locations for each and every activity from production, to distribution, to R\&D. (A formal model of such a world is presented and discussed in Agmon, 2003).

The traditional growth literature is macroeconomic by nature. It focuses on issues like the rate of savings in a given country, on monetary policy, exchange rate and such like. When development economists become more involved in the actual process of development they had to consider micro issues like investment strategy and specific policy choices. A good example of the attempt to examine issues of development economics from a more concrete point of view is presented and discussed in Balassa's discussion of the dynamics comparative advantage as a part of the process of development, (Balassa,1989). But even when Balassa discusses the competetive advantage of firms, the discussion is presented in the context of macroeconomics. Balassa argues 
in a series of articles that the changes in the comparative advantage of a number of developing countries in the 60's and the 70's was a result of an accumulation of specific capital in certain industries. Such an accumulation was often the outcome of import substitution and export promotion decisions by the government of these countries, but also the result of foreign direct investments (FDI) decisions by MNEs.

By the mid-70's when the study of the MNE became popular, the economics of International Business was rooted at Industrial Organization. By that time Development Economics was not a part of the mainstream research in economics. Krugman (1995) has suggested that this was partly due to the inability to deal with the issues of development economics in the framework of market equilibrium models. As a result of this break between Development Economics and International Business the literature on the location decisions of MNEs in the International Business literature regards national states and their policies as static impediments rather than active players. An example for this approach is Braunerhjelm and Ekholm, (1999), where the authors state at the beginning: "Over recent decades, foreign direct investment (FDI) has become a major force in the global economy. The geographical pattern of capital formation, trade and technological spillover across countries and regions, are to an increasing extent determined by the strategies chosen by multinational firms.”, (p.1). Development Economics would have suggested that governments act directly and indirectly in order to locate certain economic activities of MNEs within their borders, and that the geographical pattern of production, distribution, and R\&D by MNEs ia the result of governments’ policies.

The literature of international business did not ignore national states and the issue of the relations between states and MNEs. Early in the 70's Vernon "Sovereignty at Bay", (1971), set up the stage for the discussion of the problems caused to national states by MNEs. Twenty years later Stopford and Strange, (1991), developed a different approach to the issue of the interface between state and firm. They started their book with six general propositions. The first proposition is that states compete for means to create wealth, and the second is that the evolvement of MNEs affects the way that states compete for wealth. In the final chapter of their book Stopford and Strange provide advice both to governments and to MNEs how to deal with the structural changes of globalization, and the tension between globalization and "localness". 
In a recent paper Kobrin argues that all through the second part of the $20^{\text {th }}$ century MNE were a part of the national-state system. True, as was argued by Vernon and many others, MNEs and national states differ in their objectives. The development and the growth of the MNE makes it very difficult, if not impossible, to national state to execrsize full autonomy in their policy decisions. But "at the end of the day MNEs are international or cross-borders entities which are very much of the existing interstate system firmly rooted in national territorial jurisdiction.” (Kobrin, 2000, p. 3). Kobrin reinforces the view that although oftentimes there is a conflict between MNEs and national states, there are actors within the same system, sharing similar core values.

Neoclassical economics has taught us that international trade is based on factors of production, and in particular on factor intensity. Development Economics and International Business deal with a detailed analysis of how countries and MNEs create combinations of factors of production such that they generate and maintain comparative competitiveness, for MNEs, and comparative advantages, for countries. Comparative competitiveness and comparative advantage are the two dimensions of a value (welfare) generating matrix that both MNEs and governments are trying to attain. Discussing the interface between these two dimensions by exploring both International Business and Development Economics contributes to a better understanding of the current process of growth and income distribution in the world.

Rereading Buckley and Casson together with Hirschman enriches our understanding of how states and firms interact in creating value (welfare) in the world. This is done in two ways. First, it introduces the national states as active players into the Industrial Organization internalization paradigm used as an explanation for the growth of the MNEs. This makes the internalization model dynamic and interactive. Second, it makes a connection between the theory of the MNE as presented by Buckley and Casson and developed further by others later, and Development Economics. This connection places the growth of the MNE in a broader historical perspective. This perspective helps to understand the way by which MNEs grew in the second part of the $20^{\text {th }}$ century by looking at the MNEs as a continuation of a process of growth and the move from a close to an open economy system. This perspective contributes to a better understanding of what 
may happen in the first part of the $21^{\text {st }}$ century. (Aggarwal and Agmon, 1990, provide an example of a dynamic model that begins with import substitution and ends with international business activities).

The remaining of the paper consists of the following four sections:

2. The Two Dimensions of Internalization

3. Balanced growth, Unbalanced Growth, and the Economics of Internalizing a Market

4. Internalization, Internationalization of the Firm and Investment Choices and Strategies

5. MNEs and the Dynamics of Development

\section{The Two Dimensions of Internalization}

Internalization, as the name suggests, is the replacement of a perfect market for an output or an input where all transactions are at arm-length at the market price by some internal arrangement where prices are determined by an agreement rather than by the invisible hand of the market. When a processing firm buys a mine that supplies the raw material for the processing, internalization may follow. Where a national state creates profit opportunities by regulations such that a certain production activity is located within its borders internalization may follow as well.

At the beginning of Chapter 2 in their book Buckley and Casson state the three main postulates of their internalization model:

“(1) Firms maximize profits in a world of imperfect markets.

(2) When markets in intermediate products are imperfect, there is an incentive to bypass them by creating internal markets. This involves bringing under common ownership and control the activities which are linked by the market.

(3) Internalization across national boundaries generates MNEs.” (Buckley and Casson, 1976, p. 33). 
In a section titled “ The Paradox of the Internalization Doctrine” Hirschman writes that:

“ It states that, under the private enterprise system, entrepreneurs in underdeveloped countries will invest far less than is profitable from the point of view of society...(Therefore) Production must be integrated and centrally planned as though it were taking place in a single "trust", for only in that case are the external economies going to be "internalized" with a consequent upward revision of profit estimates” (Hirschman, 1958, p. 55). Many governments today find central planning an inefficient way to internalize. But the wish to internalize by other means as a way to attract desirable FDI persists.

Buckley and Casson present one dimension of the internalization process. Hirschman presents another dimension. But in both cases internal arrangements replace the markets, (in the sense of adherence to prices determined in complete and perfect markets). A firm may decide to locate production in a certain country as a part of its internalization process. This same decision may contribute to the process of internalizing some externalities within the borders of this country. In this case the decision of the MNE to internalize a part of the production and service chain within a given country may be independent of the interest of the government of the same country to internalize the same part of the chain of production within its borders.

In this way MNEs and governments provide internalization services for each other. Each of the actors, MNEs and governments, is trying to maximize its objective function. In a static model, each party is taking the decisions of the other actor as given. (For an example for this type of a model see the Introduction to the Symposium Multinationals: The Janus Face of Globalization, (Eden and Lenway, 2001). A more dynamic approach is to view this issue as a subject of a negotiation between the national state and the MNE. This is represented in the economic literature by game theoretic models. The solution of such models is not unique and is not stable. Using the definition of Scitovsky’s “Two Concepts of External Economies”, (Hirschman, p.65), the fact that many MNEs report positive profits indicates a "chain of disequilibria". "A chain of disequilibria is a feature of imperfect market. (In a perfectly competitive market all excess profits will disappear.)", (Hirschman, Ibid). The chain of disequilibria also implies that one expects to observe a continuous process of change in location of production, in the distribution of R\&D 
across countries, and in the ownership structure of MNEs. The business history of the last quarter of the $20^{\text {th }}$ century is consistent with this expectation.

Internalization by firms and by governments is expressed in "abnormal" high rates of profits for firms and of growth for countries. In other words, successful firms and successful governments generate and sustain "abnormal" profits from a temporary oligopolistic situation. The details may and do vary from one country to another. What is working for one country may be different that what is working for another country. MNEs do differe in their spatial expansion policy as well. South Korea in the 1980's is one example of the ability to generate and maintain high rate of growth. Singapore is another, Israel in the period 1995-2000 is yet another example where each country has found its own way to generate abnormally high rates of growth for a while in conjunction with FDI by MNEs. MNEs also found their specific strategies to generate abnormally high rates of share price appreciation. Some went the way of establishing wholly owned subsidiaries. Some opted for a joint venture startegy with local corporations, yet others build up their startegy on outsourcing.

In a somewhat more formal sense, the situation in the world market can be described as follows. Two groups of actors are operating in a set of imperfect markets. One group, the national states, has some monopolistic power over their own jurisdiction. The monopolistic power is expressed in controlling entry to their jurisdiction, and in the ability to tax, to regulate, and to discriminate among industries and firms. The second group, the MNEs has some monopolistic power over some proprietary factors of production, (i.e. knowledge), and intermediate goods and processes, (i.e. marketing channels). Governments are trying to internalize the relevant external economies and to avoid the diseconomies by offering a package of incentives to foreign firms. Firms are trying to internalize their ownership advantages by choosing the right activities to internalize and the right locations for them, and at the same time to avoid the diseconomies of internalization. The diseconomies are the outcome of fragmented markets and complex organization. MNEs are maximizing the value of their stakeholders. Governments are maximizing the economic welfare of their citizens as a way to ensure reelection. It is assumed that both governments and the managements of MNEs are acting rationally. As Buckley and Casson say: "The optimal scale,(and set of locations), is set at the margin where the costs and benefits of further 
internalization are equalized." Hirschman shares the same view where he says about internalization that: "However, if the repercussions include losses, (pecuniary external diseconomies), they will ordinarily will be internalized along with the gains and it is no longer certain where we will come out.”.

As all firms are located in one or more of the countries in the world, it is clear that there is a solution that satisfies all participants in the market, national states and MNEs. However, it is likely that there is no one optimal solution but many possible solutions and the observed (ex post) solution in any given pont of time depends on the sepcifics of the situation, or it may be randomly chosen from the set of possible solutions. This is due to the oligopolistic nature of the world market. (For a game theoretic analysis of oligopolistic market and a multiequilibria solution see Selten, (1999)). An application of a game theoretic approach to negotiation between states and MNEs is in Agmon (2003)). An added complexity is that all the stakeholders of the MNEs are also citizens in one of the countries in the world. That means that their welfare as stakeeholders may increase by the same action that decreases their welfare as citizens. An example is a decision of a MNE to relocate production in order to internalize some advantages that cannot be attained by arm-length exports. That may end with the same person losing a job as an employee and gaining value as a shareholder of the same MNE.

The way that the international distribution of the ownership advantages of MNEs changes over time, and the resulting changes in the number, the size, and the activities of the MNEs, depends crucially on the path of the development of the countries in which the MNEs operate. On the other hand, the pattern of development of national states depends on the internalization decisions of the MNEs. It is possible to specify a formal model to describe the actors, their potential moves, and to examine possible optimal strategies. Such models are found in game theory. Usually, they require specific and restricting assumptions to be tractable. An example is a model of a multistage game model with delay supergames. This situation is described as: "In a delay supergame decisions on all strategic variables are made in the same time, period after period, but this decision become effective with different delays. Thus, in period t decisions on the price in $\mathrm{t}+1$ and the capacity in $\mathrm{t}+10$ may be made, on both variable at the same time and simultaneously by all players. In a delay supergame the players have full information about previous history of 
the play, but not about simultaneous decisions made by other players. All decisions made in a period become publicly known at the beginning of the next period.”, (Selten, (1999), p.5). It is not trivial to set the problem of the interface and the competition between national states and MNEs in the restricted structure of a specific oligopolistic game like the delay supergame. It is even more difficult to interpret the solution, or in this case the many possible strategies that may lead to equilibrium. It is beyond the exploratory and descriptive nature of this paper to develop such a model and to test it both in the analytical and the empirical sense. It is sufficient in this stage to point out that the technology to set up and to analyze and test specific game theoretic models that deal with the interface between the internalization policies of national states and MNE do exist. Such models may provide a formal meeting ground for the firm oriented internalization theory of the MNE and Development Economics interpretaion of internalization with its emphasis on growth and government policies.

\section{Balanced Growth, Unbalanced Growth, and the Economics of Internalizing a Market}

This section begins with a discussion of two important features one in Buckley and Casson, and one in Hirschman. Buckley and Casson present five types of market imperfections that create incentives for firms to internalize rather than to act through arm-length transactions in the market. The presentation and the analysis of the 'balanced growth' and the 'unbalanced growth' model are central to Hirschman's discussion of development economics. The differentiation between 'balanced' and 'unbalanced' growth as a policy choice variable indicates imperfect competition. It is shown in this section that by combining Hirschman's and Buckley and Casson's models one gets a more complete picture of the imperfections that brings out internalization as an interactive process between MNEs and governments.

According to Buckley and Casson the five types of market imperfections that lead firms to internalize are:

1. The absence of developed future markets. 
2. The ability to exercise price discrimination

3. The existence of bilateral bargaining situations

4. Differences in information available to different parties

5. Barriers to trade

Examining these sources for market imperfections, it can be seen that all of them are related, though not exclusively, to the exercise of power by national states.

The absence of future markets is a sign of a restricted, or an undeveloped capital market. This is often a result of government control and regulations. In a world with no control, and free movement of capital and of information, all investors in all the countries will have an access to a one unified capital market, including future markets.

The ability to exercise effective price discrimination is often associated with an import subsistution and an export promotion policy. In such a case the government allows a firm to sell in a higher price in the domestic market as a way to prevent imports or to induce the firm to export and sell in a competitive price in external markets. This was a common feature of exportled growth in many countries. In many cases export-led growth has been a forerunner of FDI. (On this point see Aggarwal and Agmon, 1990).

It is a common practice for MNEs to enter into a bilateral bargaining with governments as a part of the decision process where to locate production, distribution centers, or a R\&D facility. In many cases the bargaining concerns reduced taxes, grants, participation in the cost of labor through training programs and such like. Changes in the prices of tradable and non-tradable factors of production as a result of the bilateral bargaining between the government and the MNE will affect location decisions by the firms. (See Buckley and Casson, pp. 49-50).

Information plays an important role in negotiations. It is also an all important factor in the specification of most game theoretic models like the one mentioned above. Differences in information can work in various ways. In some cases the government may have information about its future policies, objectives and prospects that the MNE does not have. In other cases the 
MNE may posses private information that a government does not have. As it is shown in Buckley and Casson such situations give rise to internalizing by firms, in particular to internalizing across national borders which is the essence of the MNE. Governments may want to internalize based on information about future decisions not known to the public as of now.

Barriers to trade are almost always the result of government policy and they are a direct outcome of the monopolistic power of the national state. They are also a major reason for internalization across borders.

Looking at the same issue from a different point of view is through the discussion of 'balanced' and 'unbalanced growth' provides another dimension on the issue of market imperfection. The theory of 'balanced growth' in Development Economics says that due to either supply considerations, like the lack of infrastructure, or demand considerations, like lack of absorptive income, a project that may contribute to national growth like a power station cannot succeed unless it is coordinated with other projects. For example, in order to justify an investment in a power station there is a need for an investment in a cement factory that will come on stream at the same time and will take up the slack in the demand due to low income and low demand for electricity. The investment in a cement factory through a FDI will also contribute to employment and tus for the demand for electricity by households. The 'Internalization Doctrine' of development economics says that the market cannot supply this condition and therefore the government has to step in and internalize the process by creating “artificial” market conditions. In other words, the government has to create a situation where a MNE with knowledge and marketing channels in the production of cement will decide to locate a production facility in that country.

The theory of "balanced growth" requires the government to create a complex set of preconditions like the one described above. Hirschman, argue that 'balanced growth' is unattainable, or that it leads to a no-growth policy. The alternative option is a policy of 'unbalanced growth'. A policy of 'unbalanced growth' means that the government lets the corporate sector to lead the growth, where different sectors may lead the growth in different periods. 
'Unbalanced growth' means breaking away from the restrictions on both the supply and the demand. It means investing in projects even if the infrastructure is not there, and at the time of the investment there is not enough income to buy the output resulting from the investment.

Hirschman's theory of 'unbalanced growth' was created at the time where FDI was in its infancy stages. This was so particularly regarding FDI in developing countries. As FDI developed and become more global with the development of outsourcing it makes what may look as 'unbalanced growth' from a point of view of one country feasible from the point of view of the MNE as a global system. By their nature MNEs can use their internal infrastructure, like logistics, distribution services, and internal financing to compensate for the lack of infrastructure in a certain country. In many cases the output produced by MNEs is exported, often as intermediate goods through their internal markets, or as consumer goods that are sold to the internal distribution channels of the MNEs. In this way MNEs provide both the infrastructure and the demand for the products that they manufacture in a given country. Thus what may appear as 'unbalanced growth' creates income and welfare for the residents of developing countries where MNEs have locate production. The MNEs enjoy positive profits, partly in return for their infrastructure and marketing services. Such a solution is what one expects in an oligopolistic market. The issue is how the profits of internalization are divided between the citizens of the country where 'unbalanced growth' investment is taking place, and those stakeholders of the MNEs who are not citizens in the country in question. This important issue of income distribution is not discussed here. It should be recognized, however, that much of the current discussion about globalization focuses on the question: who gets what? (For a preliminary discussion of this issue see Agmon, 2003).

The internalization process is an outcome of a joint effort by firms and by governments to maximize their objective functions in an imperfect market. Governments often generate market imperfections. The imperfections are utilized both by firms and by governments to further their goals. In some cases the goals of the two actors, MNE and government, create a mutually beneficial situation. 'Unbalanced growth' is one such case. To quote Hirschman: "it is the role of 
foreign capital to enable and to embolden a country to set out on the path of unbalanced growth”.,( Hirschman, p.205). In many cases FDI does exactly that.

\section{Internalization, Internationalization, Investment Choices and Strategies}

In the last section of chapter two, the chapter that sets up the theory of the MNE, Buckley and Casson states that: “ The theory developed above can be used to explain the pattern of the growth of the MNEs in the twentieth century. We shall argue that prior to the Second World War multinationality was a by-product of the internalization of intermediate-product market in multistage production processes, and that in the post-war period it is a by-product of the internalization of markets in knowledge.”, (Buckley and Casson, p.59).

In his analysis of investment processes Hirschman focuses on the investment activity as a function of both supply and demand. In a chapter titled: "Growth Models and Development Process" Hirschman says: "Investment is a many sided actor on the economic scene. Its simultaneous performance as income-generator and capacity-creator is the foundation of modern growth theory. Now we will stress a third role which it plays occasionally on top of the other two: that of a pace-setter for additional investment.”, (Hirschman, p.41).

Although Hirschman is talking about investment in developing countries, his analysis is an appropriate description of the role of the MNEs in the process of development in the developed world as well. The "pace-setter” role of investment in development economics, also called by Hirschman the complimentarily effect of investment, is mirrored in the Industrial Organization approach to the MNEs.

Earlier, in section 3, a difference in information was presented as a source and a reason for internalization. In response to the oligopolistic theory of "follow the leader", (Knickerbrocker, 1973), Buckley and Casson present an alternative information- based proposition. "The firm with the best market-intelligence system will be the first to recognize the opportunity for investment and sooner or later will decide to exploit it, e.g., by relocating production in the region, (the 
country).”, (Hirschman, pp.78-79). The exploitation is carried out by internalization. Often by bargaining with the government of the country in which the production is taking place.

To the extent that the investment is $R \& D$ based, as was the case many times in the process of the internalization of knowledge, the benefits for the country are large. As Hirschman points out: "The investments of one period call forth complimentary investments in the next period with a will and a logic of their own; they block out a part of the road that lies ahead and virtually compel certain additional investment decisions.”, (Hirschman, p. 42).

Buckley and Casson argue that the internalization of knowledge can explain much of the growth and the international expansion of the MNEs. Hirschman has shown that knowledgebased investment is a powerful tool of development for a country due to the complimentary effect of investment. Thus it makes sense for a government to allow a firm to attain "abnormal" profits through internalization as a way to promote growth.

In terms of the "delay supergame" referred to above, the firm and the government may have different delay periods. MNEs may have short-term profits in mind by locating R\&D based operation in a certain country, whereas the government of the country may take a longer-term view of complimentary and spill-over effects.

One way of differentiating between MNEs and national states is by their horizons. In principle governments are responsible for the future generations as well as for their current citizens. From a growth theory point of view it does make sense to "pay" for current investment by MNE, by grants, tax relief and such like, in order to create the base for future FDI that will contribute for further growth. In this respect internalization that will bring in FDI contributes to internalization of the country where the investment is located, and to future growth. In many cases the strategy and the investment choices of the government, based on long-term growth pattern, and the strategy of the MNE, maximize value subject to internalization, coincide. 


\section{MNEs and the Dynamics of Development}

The main idea expressed in this paper is that our understanding of the growth and the development of the MNEs in the second part of the $20^{\text {th }}$ century gains from examining the MNEs in the context of development economics. This is done in the first four sections of this paper by a comparative analysis of Buckley and Casson and of Hieschman. In this section the two approaches are merged where MNEs are presented as a part of the process of development.

There are several ways to present the sequence of development. A common way to do so in the literature of development economics is to begin with a closed economy and import substitution, and as the country is growing it moves to export-led growth and then to open markets and global operations. In the language of economic development this is presented as a process of opening up the economy, or moving from a close to a global economy. (For a discussion of this process see Aggarwal and Agmon, 1990).

As the national economy becomes more open, the monopoly power of the government declines. Going back to the five sources of internalization presented above, all of them, maybe with the exception of the fourth, differences in information, decline in importance as the barriers among countries become less pronounced. This means, to use Buckley and Casson terminology, that the incentive to internalize across borders declines. As, according to Buckley and Casson, internalization of markets across national boundaries generates MNEs, a decline in the incentive to internalize across national boundaries should reduce the activities of MNEs, or change the nature of the MNE in a significant way.

There is an interesting dialectics in the argument presented above. The process of opening up of the world economy, or the decline in the barriers among national states is aided by the investment decisions of the MNEs. This is so because MNEs provide bridges for the flow of information, money, people, and goods and services across borders. As Vernon (1971) has argued, the process of reducing barriers that lies in the center of the activities of the MNEs is what make them a threat to government control. Yet, MNEs depend for their existence on the national state as an organization that maintains sovereignty over a well-defined geographical 
area. The stronger is the control of the national state, ceteris paribus, the larger is the incentive of the MNE to internalize by making an investment in this state. The higher is the level of investment by MNEs in a given state, ceteris paribus, the weaker is the control of this state, and the less relevant is its geopolitical uniqueness. This is not a surprising result. Often, in monopolistic competition the actions taken by firms to realize the "abnormal" profits of the situation erase the imperfection that created the oligopoly in the first place.

The development theory, and the practice of development policy by governments, went through changes as well. The move from import substitution, to export-led growth and to global operations creates more connections among states and eroded the monopolistic power of the states. To use the term of Hettne, (1995), development theory was globalized. Some governments respond to the pressures of globalization by linking with other governments to create larger political organizations, but maintaining the geographical continuity and the political power of the state. (The European Union is the best example of this process).

The post- WWII world was shaped by the interaction between national states and MNEs. The focus of the economic research has changed following the evolving reality. Two dialectical forces, nationalism and globalization affected the second half of the $20^{\text {th }}$ century. Development Economics provided a conceptual economic structure for government policies and attaining national goals. The economics of International Business provided a conceptual structure for the development of the MNE and attaining value maximization for shareholders and stakeholders alike. Reading Buckley and Casson and Hirschman together shows that by combining the interests of both national states and MNEs, and by integrating elements from Development Economics with elements from the economics of International Business our understanding of what has happened in the past, and what may happen in the future may benefit. 


\section{References}

Aggarwal, R. and T. Agmon, - "The International Success of Developing Countries Firms: Role of Government-Directed Comparative Advantage”, MIR, 1990, pp. 163-180

Agmon, T.,- "Who Gets What: The National state, the MNE, and the Distributional Effects of Globalization”., Journal of International Business Studies, September 2003

Agmon, T. and S.J. Khouri, "Political Economy of International Diversification: The Case for Partial Diversification”., Asia-Pacific Journal of Management, Summer 1991

Balassa, B. “Comparative Advantage, Trade Policy, and Economic development”, New Yoek University Press, NY 1989

Braunerhjelm, P. and K. Ekholm, (eds.), - “The Geography of Multinational Firms”, Kluwer Academic Publishers, Boston, MA 1998

Buckley, P.J. and M. Casson, - “The Future of the Multinational Enterprise”, The Macmillan Press, London, 1976

Caves, R.E., -“International Corporations: The Industrial Economics of Foreign Investment”, Economica, 38(1971), pp. 1-27

Eden, L. and S. Lenway, "Introdusction to the Symposium on Multinationals: The Janus Face of Globalization”., Journal of International Business Studies, September 2001, pp.383-401

Globerman, S. and D.M. Shapiro, “The Impact of Government Policies on Foreign Direct Investment: The Canadian Experience”, Journal of International Business Studies, vol. 30, No. 3, Third Quarter 1999, pp. 513-22

Hettne, B. - “Development Theory and the Three Worlds”, Longman Scientific and Technical, Essex, England, 1975

Hirschman, A.O. - “The Strategy of Economic Development”, Yale University Press, New Haven, CT 1958

Hymer, S. - "The International Operations of National Firms: A Study of Direct Foreign Investment”, MIT Press, Cambridge, MA 1976

Kindleberger, C.P. - “American Business Abroad”, Yale University Press, New Haven, CT 1969

Kobrin, S.J., - "Sovereignty @ Bay: Globalization, The International Political System and Multinational Enterprise.”, Oxford Handbook of International Business, Oxford, 2000

Krugman, P. “Development, Geography, and Economic Theory”, MIT Press, MA, 1995 
Selten, R. - "Game Theory and Economic Behaviour”, Selected Essays, Volume Two., Edward Elgar, Cheltenham, UK, 1999

Stopford, J. and S. Strange, - “Rival States, Rival Firms”, Cambridge University Press, Cambridge, 1991

Vernon, R. - “Sovereignty at Bay”, Basic Books, New York, 1971 


\section{DAVIDSON INSTITUTE WORKING PAPER SERIES - Most Recent Papers}

The entire Working Paper Series may be downloaded free of charge at: www.wdi.bus.umich.edu

CURRENT AS OF 11/4/2004

\begin{tabular}{|c|c|c|}
\hline Publication & \begin{tabular}{|l|} 
Authors \\
\end{tabular} & Date \\
\hline $\begin{array}{l}\text { No. 725: International Business and Development Economics: A } \\
\text { Winning Combination }\end{array}$ & Tamir Agmon & Nov. 2004 \\
\hline $\begin{array}{l}\text { No. 724: Importing High-Risk Capital and Revealing Hidden } \\
\text { Comparative Advantages }\end{array}$ & Tamir Agmon & Oct. 2004 \\
\hline $\begin{array}{l}\text { No. 723: Which entrepreneurs expect to expand their businesses? } \\
\text { Evidence from survey data in Lithuania }\end{array}$ & $\begin{array}{l}\text { Ruta Aidis and Tomasz } \\
\text { Mickiewicz }\end{array}$ & Oct. 2004 \\
\hline No. 722: Russia from Bust to Boom: Oil, Politics or the Ruble? & $\begin{array}{l}\text { Bruno Merlevede and Koen } \\
\text { Schoors }\end{array}$ & Oct. 2004 \\
\hline No. 721: Distance to the Efficiency Frontier and FDI Spillovers & \begin{tabular}{|l} 
Klara Sabirianova Peter, Jan \\
Svejnar, and Katherine Terrell
\end{tabular} & Sept. 2004 \\
\hline $\begin{array}{l}\text { No. 720: An Analysis of Gender Wage Differentials in Russia from } \\
\text { 1996-2002 }\end{array}$ & Rita Hansberry & Sept. 2004 \\
\hline $\begin{array}{l}\text { No. 719: Returns to Schooling in Russia and Ukraine: } \\
\text { A Semiparametric Approach to Cross-Country Comparative Analysis }\end{array}$ & \begin{tabular}{|l|} 
Klara Sabirianova Peter and \\
Yuriy Gorodnichenko \\
\end{tabular} & Sept 2004 \\
\hline $\begin{array}{l}\text { No. 718: The emergence of large shareholders in mass privatized } \\
\text { firms: Evidence from Poland and the Czech Republic }\end{array}$ & Irena Grosfeld and Iraj Hashi & Aug. 2004 \\
\hline $\begin{array}{l}\text { No. 717: Wage Determination Under Communism and In Transition: } \\
\text { Evidence from Central Europe }\end{array}$ & $\begin{array}{l}\text { Swati Basu, Saul Estrin and Jan } \\
\text { Svejnar }\end{array}$ & Aug. 2004 \\
\hline No. 716: The Evolution of Cross-Region Price Distribution in Russia & Konstantin Gluschenko & July 2004 \\
\hline $\begin{array}{l}\text { No. 715: Languages in the European Union: The Quest for Equality and } \\
\text { its Cost }\end{array}$ & $\begin{array}{l}\text { Jan Fidrmuc and Victor } \\
\text { Ginsburgh }\end{array}$ & July 2004 \\
\hline $\begin{array}{l}\text { No. 714: Voice of the Diaspora: An Analysis of Migrant Voting } \\
\text { Behavior }\end{array}$ & Jan Fidrmuc and Orla Doyle & July 2004 \\
\hline $\begin{array}{l}\text { No. 713: International Coercion, Emulation and Policy Diffusion: } \\
\text { Market-Oriented Infrastructure Reforms, 1977-1999 }\end{array}$ & $\begin{array}{l}\text { Witold J. Henisz and Bennet A. } \\
\text { Zelner and Mauro F. Guillen }\end{array}$ & July 2004 \\
\hline $\begin{array}{l}\text { No. 712: Votes and Vetoes: The Political Determinants of Commercial } \\
\text { Openness }\end{array}$ & $\begin{array}{l}\text { Witold J. Henisz and Edward D. } \\
\text { Mansfield }\end{array}$ & July 2004 \\
\hline $\begin{array}{l}\text { No. 711: Interest Groups, Veto Points and Electricity Infrastructure } \\
\text { Deployment }\end{array}$ & $\begin{array}{l}\text { Witold J. Henisz and Bennet A. } \\
\text { Zelner }\end{array}$ & July 2004 \\
\hline $\begin{array}{l}\text { No. 710: Firms' Price Markups and Returns to Scale in Imperfect } \\
\text { Markets: Bulgaria and Hungary }\end{array}$ & $\begin{array}{l}\text { Rumen Dobrinsky, Gábor Körösi, } \\
\text { Nikolay Markov, and László } \\
\text { Halpern } \\
\end{array}$ & July 2004 \\
\hline $\begin{array}{l}\text { No. 709: The Stability and Growth Pact from the Perspective } \\
\text { of the New Member States }\end{array}$ & Gábor Orbán and György Szapáry & July 2004 \\
\hline $\begin{array}{l}\text { No. 708: Contract Violations, Neighborhood Effects, and Wage Arrears } \\
\text { in Russia }\end{array}$ & $\begin{array}{l}\text { John S. Earle and Klara } \\
\text { Sabirianova Peter }\end{array}$ & July 2004 \\
\hline $\begin{array}{l}\text { No. 707: Determinants of Employment Growth at MNEs: Evidence } \\
\text { from Egypt, India, South Africa and Vietnam }\end{array}$ & $\begin{array}{l}\text { Sumon Kumar Bhaumik, Saul } \\
\text { Estrin and Klaus Meyer }\end{array}$ & July 2004 \\
\hline $\begin{array}{l}\text { No. 706: Economic Reform in Tanzania and Vietnam: A Comparative } \\
\text { Commentary }\end{array}$ & $\begin{array}{l}\text { Brian Van Arkadie and Do Duc } \\
\text { Dinh }\end{array}$ & June 2004 \\
\hline $\begin{array}{l}\text { No. 705: Beliefs about Exchange-Rate Stability: Survey Evidence } \\
\text { from the Currency Board in Bulgaria }\end{array}$ & $\begin{array}{l}\text { Neven T. Valev and John A. } \\
\text { Carlson }\end{array}$ & June 2004 \\
\hline No. 704: Returns to Schooling in China Under Planning and Reform & $\begin{array}{l}\text { Belton M. Fleisher and Xiaojun } \\
\text { Wang }\end{array}$ & June 2004 \\
\hline $\begin{array}{l}\text { No. 703: Return to Skills and the Speed of Reforms: Evidence from } \\
\text { Central and Eastern Europe, China and Russia }\end{array}$ & \begin{tabular}{|l|} 
Belton M. Fleisher, Klara \\
Sabirianova Peter, and Xiaojun \\
Wang \\
\end{tabular} & June 2004 \\
\hline $\begin{array}{l}\text { No. 702: What Makes Small Firms Grow? Finance, Human Capital, } \\
\text { Technical Assistance, and the Business Environment in Romania }\end{array}$ & $\begin{array}{l}\text { J. David Brown, John S. Earle } \\
\text { and Dana Lup }\end{array}$ & May 2004 \\
\hline $\begin{array}{l}\text { No. 701: The Effects of Multiple Minimum Wages Throughout the } \\
\text { Labor Market }\end{array}$ & $\begin{array}{l}\text { T. H. Gindling and Katherine } \\
\text { Terrell }\end{array}$ & May 2004 \\
\hline No. 700: Minimum Wages, Inequality and Globalization & $\begin{array}{l}\text { T. H. Gindling and Katherine } \\
\text { Terrell }\end{array}$ & May 2004 \\
\hline
\end{tabular}

